\title{
Gender gap in the impact of social capital on household food security in Zimbabwe: does spatial proximity matter?
}

\section{Terrence Kairiza $^{1} \cdot$ George Kembo $^{2} \cdot$ Vengesai Magadzire $^{3} \cdot$ Lloyd Chigusiwa $^{1}$}

Received: 7 August 2020 / Accepted: 30 October 2021 / Published online: 19 November 2021

(c) The Author(s) 2021

\begin{abstract}
Despite the numerous strides that have been made towards ensuring food security since the launch of the United Nations Millennium Development Goals (MDGs), the gap between the rich and poor across and within countries is still worryingly too large. Around $57.7 \%$ of the Sub-Saharan Africa (SSA) population is food insecure compared to $26.4 \%$ of the world population. It is therefore necessary to make concerted efforts to improve food security in Sub-Saharan Africa and the rest of the developing world particularly among the poorest and most vulnerable groups. This paper employs propensity score matching analysis to explore gender heterogeneity in the impact of bonding and bridging social capital on household food security on the basis of a nationally representative sample of Zimbabwean households. It offers five major findings. First, female headed households are more likely to have bonding social capital than their male counterparts. Second, there are no gender differences in the household's ability to possess bridging social capital. Third, household spatial proximity to households with social capital improves the probability of the household possessing social capital. Fourth, both bonding and bridging social capital improves household food security. Finally, female headed households are more able to increase food security than those headed by males when they have both bonding and bridging social capital. The study argues that coping strategies should target putting the family at the core of inclusive development agendas such as food and nutrition assistance programmes in order to maximise the likelihood of easing food insecurity within communities.
\end{abstract}

Keywords Gender differences $\cdot$ Food security $\cdot$ Social capital

Terrence Kairiza

tkairiza@yahoo.com

1 Department of Economics, Bindura University of Science Education, P. Bag 1020, Bindura, Zimbabwe

2 Food and Nutrition Council of Zimbabwe, 1574 Alpes Road, Hatcliffe, Harare, Zimbabwe

3 RGMSchool of Intelligence, No. 20 Homestead Msasa, Harare, Zimbabwe 


\section{Introduction}

Goal 2 of the second United Nations Sustainable Development Goals (SDGs) is to end hunger and ensure access to safe, nutritious and sufficient food all year round by all people by the year 2030, in particular the poor and people in vulnerable situations. Whilst the rest of the world made substantial strides towards attaining food security, the majority of countries in South Asia, Latin America and Sub-Saharan Africa (SSA) still lag behind (FAO, 2015; FAO et al., 2019). Whereas North America and Europe recorded only about $8 \%$ of their population as being food insecure, $57.7 \%$ of the population in Sub-Saharan Africa is food insecure - in South Asia it is $34.3 \%$ and $30.9 \%$ in Latin America (FAO et al., 2019). In addition to having the highest proportion of the population that is food insecure, it is even more disconcerting to note that Sub-Saharan Africa records the highest proportion of the severely food insecure population (24.6\%).According to FAO et al. (2019) severe food insecurity means people have likely run out of food, experienced hunger or in extreme cases have gone for days without eating.

Banerjee and Duflo (2011) note that the consequences of food insecurity are debilitating to long run economic development, including but not limited to, poor general health (Gundersen \& Kreider, 2009), mental health problems (Huang et al., 2010) and cognitive impairment (Howard, 2011). Food insecurity is thus a scourge which may propagate a vicious cycle of poverty among the affected regions since it hinders them from reaching their cognitive and productive potential. Recent studies have started to look at household social capital as a potential explanatory factor to aid poor households in combating food insecurity (e.g. Lee et al., 2018) and a host of other outcomes (e.g. Ehsan et al., 2019). In environments where institutional quality is low, social capital embodied in trust and reciprocity improves efficiency in economic exchange, concomitantly meliorating household outcomes such as food security (Acemoglu et al., 2005; Durlauf \& Fafchamps, 2005; Fafchamps \& Minten, 1999). The efficacy of social capital in improving household outcomes depends on the form of social capital under consideration. Putnam (2000) differentiates bonding social capital which is based around family, close friends and other near kin from bridging social capital which links people to more distant acquaintances. Putnam (2000) contends that, while bonding social capital is effective in improving basic household outcomes such as food security, bridging social capital is crucial for improving complex household outcomes such as employment status of household members.

Household acquisition and usage of social capital is inter alia dependent on background characteristics of the household head including gender and spatial proximity to other households. Studies that focus specifically on gender heterogeneity in the impact of social capital on food security incorporating spatial proximity to other households that have social capital are of great interest. To the best of our knowledge, studies that combine these three issues are scarce; probably because data on social capital, spatial proximity, as well as food security are rarely found in the same data sets. This paper adds to the body of knowledge on social capital by bridging this gap on the basis of a large scale data collected in Zimbabwe by the Zimbabwe Vulnerability Assessment Committee (ZimVAC) in 2019.

Specifically, the research seeks to answer the following four questions. Firstly, to what extent does the gender of the household head affect the propensity of a 
household to possess social capital? Secondly, to what extent does spatial interdependence affect the amount of social capital that the household has? Thirdly, does social capital influence the food security status of the household? Finally, is there heterogeneity in the impact of social capital on household food security on the basis of the gender of the household head?

Identification of the linkage between social capital and household food security using observational data is confounded by self-selection bias associated with the ownership of social capital (Heckman et al., 1997; Austin, 2011). We employ propensity score matching (PSM) to cater for the self-selection bias associated with the household ownership of social capital. Furthermore, we check for the robustness of the propensity score matching results using the Inverse Probability Weighting Regression Adjustment approach (IPWRA).

The paper offers five major findings. Firstly, female-headed households are more likely to have bonding social capital than their male counterparts. Secondly, there are no gender differences in the household's ability to possess bridging social capital. Thirdly, spatial proximity to households with social capital improves the probability of a household possessing social capital. Fourthly, both bonding and bridging social capital improves household food security. Finally, female headed households are more able to increase food security than their male counterparts when they have both bonding and bridging social capital.

The rest of the paper proceeds as follows; Section 2 reviews relevant literature and outlines hypotheses to be examined in this study. Section 3 details the materials and methods employed in the study, whilst Section 4 provides a discussion of the results. Finally, Section 5 concludes.

\section{Literature review and hypotheses}

Food security forms the bedrock which supports human existence and prosperity. If members of the household are poverty stricken and undernourished, they are always sickly and too weak to produce. Food insecure households often devote less time and energy towards production of food which exacerbates food insecurity, thereby creating a vicious circle (Banerjee \& Duflo, 2011). Consequently, households experiencing food insecurity today are likely impaired from extricating themselves from future food insecurity. The impairments that emanate from food insecurity include health impairment (Gundersen \& Kreider, 2009), mental impairment (Huang et al., 2010), cognitive impairment (Howard, 2011) and a weak capital base which compromises their creditworthiness in case they want to secure loans. These various impairments affect the household's ability to produce enough food for themselves through compromising on energy, decision making ability and institutional assistance to expand their production. A diversity of factors that can be utilised to improve food security has been reviewed in literature and social capital has of late been targeted as another of those potential factors (Lee et al., 2018; Ehsan et al., 2019).

Social capital is a form of informal institution which corrects inadequacies of formal institutions to bring stability to market exchange in settings with weak formal institutions (Acemoglu et al., 2001 2002; Williamson \& Easterly, 2015; Giordano et al., 2015). Social capital, in the form of cultural values, norms and beliefs, and 
social cohesion is thus considered as the panacea that bridges formal institutions inadequacies (Acemoglu et al., 2005). Social capital complement, modify and substitute dysfunctional formal institutions to establish trust, reputation and inter-agent relations (Akerlof, 1970; Fafchamps \& Minten, 1999).

Changes in society and social structure, such as wealth distribution, age demography, value systems and beliefs, urbanisation, migration and globalisation, may bring about inefficiencies in economic, social and political functionality due to the delay and inability of formal institutions to adapt to the changes (e.g. Bourdieu et al., 1992). Informal institutions therefore either bridge or fill the gap caused by the lag in response of formal institutions to structural change in order to restore efficiency (Akerlof 1970; Fafchamps \& Minten, 1999). However, the process of adjustment by informal institutions towards efficiency is not always smooth as it is often marred with polarisation and conflict emanating from divergences in beliefs, orientation, origin, age and gender structures (Jennings \& Sanchez-Pages, 2017). The process of convergence within social groupings thus depends on the willingness of group participants to compromise. The extent to which a household is willing to cooperate through compromising as a member of a social grouping depends on factors like the gender of the household head and the household's perception of other households' reaction to their action.

There are significant gender differences on disaggregated cooperation rates within social groupings (Charness \& Rustichini, 2011; Croson et al., 2008). Females signal cooperativeness in both bonding and bridging relations while males signal cooperativeness only in bridging relations and formidability in bonding relations (e.g. Charness \& Rustichini, 2011). One possible explanation to this dynamic is that females are more risk averse compared to males (Croson \& Gneezy, 2009; Eckel \& Grossman, 2008) and thus fear reprisals from their social groups more than their male counterparts (Brody, 1993). This leads us to our first hypothesis, which we subdivide into two:

H1.1. Female-headed households are more likely to have bonding social capital than their male counterparts.

H1.2. There are no gender differences in the household propensity to have bridging social capital.

Intra-community 'bonding' ties provide families with a sense of identity and belonging which compels them to work with a common purpose (Astone et al., 1999; Chriest \& Niles, 2018). The same view also stresses that intercommunity 'bridging' ties broadens the scope of interests that households and communities pursue but are often weak. Empirical literature reinforces the argument by proving that poor families tend to live clustered together with very strong bonding relations and lack broadened bridging relations which is a phenomenon highly associated with well to do households and communities (Kozel \& Parker, 2000; Moser \& Holland, 1998; Woolcock \& Narayan, 2000). This leads to our second hypothesis:

H2. Households are more likely to be spatially located in proximity to other households with similar form of social capital. 
During times of stress due to food supply shocks, households in developing countries can bank on their social capital through kinship, solidarity and mutual cooperation to facilitate access to food (Kuwabara, 2005; Lippman et al., 2013; Misselhorn, 2009). Ordinarily, when faced with food insecurity, households look to formal government and non-governmental institutions for relief and social protection. However, formal institutions have deficiencies which exclude various groups from benefiting (Thorat, 2009). Some of the exclusion factors include political affiliation, religion, ethnicity, gender, perceptions and information asymmetry among others. This results in various groups forming local partnerships based on mutual understanding to plug the exclusion gap and aid each other during times of need (Stavropoulou et al., 2016). We therefore propose the following hypothesis linking social capital to food security:

H3. Social capital improves household food security status.

Both formal and informal assistance during times of food stress seems to favour women more than men. Formal institutions often use algorithms that prioritise women such as widows and single mothers when providing food assistance in communities threatened by food insecurity (e.g., Lenhart, 2021). Informal institutions likewise value mutual trust and females are considered more trustworthy compared to males (Gilligan, 1982). On average, women have more to lose by failing to cooperate in societal programmes. If households cooperate with other households by adopting a socially responsible action, they avoid possible punishment in the form of local level sanctions (Bardhan, 1997). They also reduce the opportunity cost of working in an untrustworthy manner, which improves future transactional engagement (Granovetter, 1985; Durlauf \& Fafchamps, 2005). This solves the free-rider problem by reducing opportunism and selfish behaviour through interactive means (e.g., Abreu, 1988).

Women perceive themselves as part of a network of social relations and consider themselves morally obligated to contribute to their network's welfare (e.g. Gilligan, 1982). Men, on the other hand, underscore their rights as individuals over the group and view their environment as a system of hierarchical relationships (e.g., Eagly, 1987). Gender differences in perceptions of social relations are the basis of gender heterogeneity in the kind of assistance and reciprocal services received from social relations. We therefore infer that the high likelihood of females to cooperate in social activities increases their chances of receiving assistance during times of stress. We therefore advance the following hypothesis linking gender, social capital and food security:

H4. Female-headed households with social capital are more able to increase their food security status compared to male headed households.

\section{Materials and methods}

\subsection{Sample}

This paper uses a nationally representative household data on rural and urban livelihoods from the 2019 cross-section surveys conducted by the Zimbabwe Vulnerability Assessment Committee (ZimVAC) which is a consortium comprising 
of the Zimbabwean government, UN agencies and non-governmental organisations. The total sample size comprises16,556 households with 9926 households in the rural areas and 6630 households in urban areas. The gender disaggregation of the total sample comprises 8053 female-headed households and 8503 male-headed households.

\subsection{Measurement of key variables}

\subsubsection{Household food security}

This study uses the household dietary diversity score as a proxy for the household food security status. According to Ruel (2002) household dietary diversity is a useful indicator of household food security since it encapsulates the main components of food security. Similar studies that have used dietary diversity score to proxy food security include (Shaw, 2007; Gibson, 2012; Carletto et al., 2013). Dietary diversity is a measure of how many foods or food groups a household consumes over a given period of time. We derive the household dietary diversity score by measuring how many food groups out of 12 , were consumed by the household during the week preceding the survey. Consequently the household dietary diversity score ranges from 0 to 12 . The higher the household dietary diversity score the more food secure the household is.

\subsubsection{Household social capital}

This study uses two questions to measure whether the household possesses bonding or bridging social capital. According to van Staveren and Knorringa (2007), bonding and bridging social capital can be conceptualised as different types of trust where 'earned' trust relates to bridging relations and ascribed trust relates to bonding relations. Thus the two questions ask whether the household trusts that they can lean on relatives or non-relatives for food related assistance ${ }^{1}$. The question specifically says "Do you trust that your household will be able to lean on relatives/non-relatives for food related assistance?”. The two questions are not mutually exclusive, as the household can have both bonding and bridging social capital. Thus each question takes the value of one for bonding (bridging) social capital if the household answered in the affirmative to either exclusively lean on relatives (non-relatives) or both and zero otherwise (see Table 2). Owing to the difficulties related to the measurement of social capital, we also use actual reception of food related assistances from relatives and non-relatives as alternative measures of bonding and bridging social capital, respectively to check the robustness of our results. The actual question that speaks of reception of support in our questionnaire says "During the last 12 months, did your household receive food related assistance from relatives/non-relatives?”.

\footnotetext{
1 Where context is first given that food assistance from non-relatives mean non-institutional food assistance from individuals and households who are not related to any member of the household.
} 


\subsubsection{Number of neighbours with social capital}

To measure the household's number of neighbours with bonding or bridging social capital, we utilised Euclidean distance in metres between the households that we computed using the household GPS coordinate information. The number of neighbours with bonding or bridging social capital is simply the number of people within the $10 \mathrm{~km}$ radius of the household who also possesses the same social capital.

\subsubsection{Female headed household}

We take the United Nations (2017) definition of a household as a group of persons who make common provision of food, shelter and other essentials for living. In that case the household head is the person who makes the major decisions pertaining to the functioning of that household. A household is taken to be female headed if the gender of that person is female.

\subsection{Econometric specification}

\subsubsection{The impacts of gender and spatial proximity on social capital}

To test Hypotheses 1.1, 1.2 and 2 of this study, which speaks to the impact of gender (Hypotheses 1.1 and 1.2) and spatial proximity to households with social capital (Hypothesis 2) on the probability of the household having social capital respectively, we employ binary response models as follows:

$$
\begin{aligned}
& \operatorname{Pr}\left(S_{i}=1\right) \\
& =f\left(\alpha+\beta_{1} \text { Female }_{i}+\beta_{2} \text { Bonding }_{i}+\beta_{3} \text { Bridging }_{i}+X_{i}^{\prime} \gamma+\varepsilon_{i}\right) \quad \mathrm{i}=1, . . \mathrm{N}
\end{aligned}
$$

where $\mathrm{S}_{\mathrm{i}} \in\{0,1\}$ is the household social capital status and $f^{*}()$ represents the logistic function. Female Fe $_{i} \in\{0,1\}$ is a dummy variable indicating the gender of the household head, which takes the value of 1 if the household head is female and 0 otherwise. Bonding $_{i}$ and Bridging B $_{i}$ is the number of neighbours within $10 \mathrm{~km}$ radius to household $i$ with bonding and bridging social capital respectively. $\boldsymbol{X}_{\boldsymbol{i}}$ is a vector of the household background characteristics. We cluster the standard errors at the district level and present the results in Table 4 of this paper.

\subsubsection{The impact of social capital on food security}

Assessing the impact of social capital on food security using observational data is confounded by incomplete information arising from the self-selection of observations into social capital (Austin, 2011; Caliendo \& Kopeinig, 2008; Heckman et al., 1997). Propensity Score Matching (PSM) is used to reduce the confounding effects of observational survey data as observational or non-randomized studies always suffer from selection bias unlike randomized control trials (RCTs).

We define an indicator variable, $S_{i}$, which takes the value of 1 for household i, if the household has social capital and 0 , otherwise. We also define the food security of household which is proxied by the household dietary diversity score as $Y_{i}$. The 
counterfactual problem is that for each household we can only observe either $Y_{i 0}$, or $Y_{i 1}$ which is the food security when $S_{i}=1$ and $S_{i}=0$, respectively.

Propensity score matching techniques circumvent the counterfactual problem by matching $S_{i}=1$ and $S_{i}=0$ households using $\operatorname{Pr}\left(S_{i}=1 \mid \mathrm{X}\right)$ which is the probability of household i having $S_{i}=1$ on the basis of observed covariates, $\mathbf{X}_{\mathbf{i}}$. In this study, we use nearest neighbour matching technique which chooses an individual from the comparison group for treated individual that is closest in terms of propensity score. We estimate the average treatment effect on the treated (ATT) that provides the impact of social capital on food security and gender effects of social capital on food security as follows:

$$
\mathrm{ATT}=E\left(Y_{i 1} \mid S_{i}=1\right)-E\left\{E\left(Y_{i 0}\left|S_{i}=0, \operatorname{Pr}\left(S_{i}=1 \mid X\right)\right| S_{i}=1\right)\right\}
$$

The validity of the ATT requires the conditional independence assumption that assignment to $S_{i}=1$ or $S_{i}=0$ is random after controlling for observed covariates X (Austin, 2009; 2011; Caliendo \& Kopeinig, 2008; Heckman et al., 1997). We implement PSM and estimate treatment effects and present the results in Table 4 which portray the tests to Hypothesis 3 .

To test Hypothesis 4 which examines gender heterogeneity in the impact of $S_{i}=1$ on the basis of the gender of the household head, Female ${ }_{i}$, which takes the value of 1 if the household head is female and 0 otherwise. We separately estimate Average Treatment Effects on the Treated (ATT) from Eq. (2) and present the results in Table 5 .

For both Hypothesis 3 and Hypothesis 4, we also employ the Inverse Probability Weighted Regression Adjustment method (IPWRA) as a robustness check measure.

\section{Results and discussion}

\subsection{Descriptive analysis}

\subsubsection{Background characteristics of sampled households}

Table 1 shows the background characteristics of the sampled households by the gender of the household head. The table display marked gender differences in the household characteristics. The table shows that female household heads are less likely to be married and living together with their spouses than their male counterparts. The respective proportions of female and male household heads who are married and living together with their spouses are 41.7 versus $88.8 \%$. The difference is significant at the $1 \%$ level of significance. The high number of female headed households that are married and living together with their spouses of $41.7 \%$ might seem a misnomer for a patriachial society like Zimbabwe. This nevertheless can be explained to a greater extent by the high levels of polygamy in developing countries. A woman whilst married to her polygamous husband makes the most important decisions pertaining to the functioning of her household. In Zimbabwe the highest number of polygamous marriages are among the apostolic sects religion which encourages such kind of marriages. Incidentally, $29.5 \%$ of the surveyed households falls under the apostolic sects religion. 
Table 1 Background characteristics by gender of the household head

\begin{tabular}{|c|c|c|c|c|c|}
\hline & \multicolumn{2}{|l|}{ Female } & \multicolumn{2}{|l|}{ Male } & \multirow{2}{*}{$\begin{array}{l}\text { Difference } \\
\text { in means }\end{array}$} \\
\hline & Mean & S.D & Mean & S.D & \\
\hline Number of observations \# [\%] & 8053 & {$[48.69 \%]$} & 8503 & {$[51.31 \%]$} & \\
\hline Household head age [Years] & 42.705 & 17.327 & 43.777 & 15.759 & $-1.073 * * *$ \\
\hline \multicolumn{6}{|l|}{ Marital status of household head } \\
\hline Married living together & 0.417 & 0.493 & 0.887 & 0.317 & $-0.470 * * *$ \\
\hline Married living apart & 0.124 & 0.330 & 0.035 & 0.183 & $0.089 * * *$ \\
\hline Divorced/separated & 0.115 & 0.319 & 0.015 & 0.120 & $0.100 * * *$ \\
\hline Widow/widower & 0.276 & 0.447 & 0.020 & 0.139 & $0.257 * * *$ \\
\hline Never married & 0.059 & 0.236 & 0.038 & 0.191 & $0.021 * * *$ \\
\hline Not applicable & 0.009 & 0.093 & 0.006 & 0.077 & $0.003 * *$ \\
\hline \multicolumn{6}{|l|}{ Education level of household head } \\
\hline None & 0.135 & 0.341 & 0.072 & 0.259 & $0.062 * * *$ \\
\hline Primary level & 0.331 & 0.470 & 0.275 & 0.446 & $0.056^{* * *}$ \\
\hline ZJC level & 0.139 & 0.346 & 0.118 & 0.323 & $0.020 * * *$ \\
\hline O' level & 0.337 & 0.473 & 0.432 & 0.495 & $-0.094 * * *$ \\
\hline A' level & 0.016 & 0.126 & 0.035 & 0.183 & $-0.018 * * *$ \\
\hline Diploma/Certificate after primary & 0.004 & 0.067 & 0.006 & 0.079 & $-0.002 *$ \\
\hline $\begin{array}{l}\text { Diploma/Certificate after } \\
\text { secondary }\end{array}$ & 0.024 & 0.154 & 0.034 & 0.181 & $-0.010 * * *$ \\
\hline Graduate/Post-Graduate & 0.012 & 0.110 & 0.025 & 0.158 & $-0.013 * * *$ \\
\hline \multicolumn{6}{|l|}{ Religion of household head } \\
\hline Roman Catholic & 0.097 & 0.296 & 0.079 & 0.269 & $0.018 * * *$ \\
\hline Protestant & 0.109 & 0.312 & 0.083 & 0.275 & $0.026^{* * *}$ \\
\hline Pentecostal & 0.211 & 0.408 & 0.159 & 0.366 & $0.053 * * *$ \\
\hline Apostolic Sect & 0.295 & 0.456 & 0.276 & 0.447 & $0.018^{* *}$ \\
\hline Zion & 0.093 & 0.290 & 0.082 & 0.274 & $0.011 * *$ \\
\hline Other Christian & 0.076 & 0.265 & 0.063 & 0.243 & $0.013 * * *$ \\
\hline Islam & 0.005 & 0.071 & 0.009 & 0.093 & $-0.004 * * *$ \\
\hline Traditional & 0.014 & 0.119 & 0.030 & 0.172 & $-0.016^{* * *}$ \\
\hline Other religion & 0.016 & 0.126 & 0.019 & 0.135 & -0.002 \\
\hline No religion & 0.072 & 0.258 & 0.169 & 0.375 & $-0.098 * * *$ \\
\hline Not applicable & 0.012 & 0.108 & 0.032 & 0.175 & $-0.020 * * *$ \\
\hline \multicolumn{6}{|l|}{ Other Household attributes } \\
\hline Household size & 4.727 & 2.200 & 4.977 & 2.154 & $-0.250 * * *$ \\
\hline Household income [ZWL] & 533 & 1166 & 627 & 1460 & $-94 * * *$ \\
\hline Number of mentally ill members & 0.121 & 0.396 & 0.143 & 0.435 & $-0.022 * * *$ \\
\hline $\begin{array}{l}\text { Number of chronically ill } \\
\text { members }\end{array}$ & 0.094 & 0.346 & 0.079 & 0.329 & $0.014 * * *$ \\
\hline Members with mother alive & 2.157 & 1.569 & 2.176 & 1.531 & -0.019 \\
\hline Members with father alive & 1.844 & 1.504 & 2.066 & 1.474 & $-0.221 * * *$ \\
\hline Household is located in rural area & 0.600 & 0.490 & 0.600 & 0.490 & 0.001 \\
\hline
\end{tabular}


Table 1 continued

\begin{tabular}{|c|c|c|c|c|c|}
\hline & \multicolumn{2}{|c|}{ Female } & \multicolumn{2}{|l|}{ Male } & \multirow{2}{*}{$\begin{array}{l}\text { Difference } \\
\text { in means }\end{array}$} \\
\hline & Mean & S.D & Mean & S.D & \\
\hline \multicolumn{6}{|l|}{ Province } \\
\hline Bulawayo & 0.022 & 0.145 & 0.020 & 0.140 & 0.002 \\
\hline Manicaland & 0.074 & 0.262 & 0.078 & 0.267 & -0.004 \\
\hline Mash Central & 0.069 & 0.254 & 0.074 & 0.262 & -0.005 \\
\hline Mash East & 0.146 & 0.353 & 0.133 & 0.340 & $0.013^{* *}$ \\
\hline Mash West & 0.114 & 0.318 & 0.173 & 0.378 & $-0.059^{* * *}$ \\
\hline Mat North & 0.078 & 0.269 & 0.083 & 0.275 & -0.004 \\
\hline Mat South & 0.151 & 0.358 & 0.115 & 0.319 & $0.036^{* * * *}$ \\
\hline Midlands & 0.146 & 0.353 & 0.142 & 0.349 & 0.004 \\
\hline Masvingo & 0.128 & 0.334 & 0.100 & 0.300 & $0.028 * * *$ \\
\hline Harare & 0.073 & 0.260 & 0.082 & 0.275 & $-0.010^{* *}$ \\
\hline
\end{tabular}

Notes: Total sample size is 16,556. The final column shows the results of two-tailed $t$-test for the difference in the means. $* * *, * *$, and $*$ indicate the 1,5 , and $10 \%$ levels of significance

Furthermore, female household heads tend to be younger and less educated than their male counterparts. On average female household heads are about 1 year younger than their male counterparts and the age difference by gender is also significant at $1 \%$ level of significance. With regards to education, a proportion of $13.5 \%$ female household heads never attended school at all compared to $7.2 \%$ of their male counterparts. For higher levels of educational attainment from 'O' Level to university graduates, female household heads comprise a lesser proportion compared to their male counterparts.

The results in Table 1 further indicate that at the $1 \%$ level of significance, female headed households tend to be smaller in terms of size and poorer in terms of income than their male counterparts before controlling for observed confounding variables. On average, female headed households earn about ZWL94 (approximately US\$6.40) less than male headed households.

\subsubsection{Household social capital and food security by gender of the household head}

The first panel of Table 2 displays that at the $10 \%$ level of significance female headed households are $1.1 \%$ more likely to possess bonding social capital than their male counterparts. There is however no statistically significant gender differences in the household propensity to possess bridging social capital before controlling for observed confounding variables. The results presented in the first panel are robust to the change in the measure of social capital to having actually received food related assistance in the past 12 months.

Table 3 shows that female headed households are less likely to have neighbours in their $10 \mathrm{~km}$ radius with bonding or bridging social capital than their male counterparts before controlling for observed confounders. There is however no statistically significant gender gap in the household food security as proxied by the household 
Table 2 Social capital status by gender of the household head

\begin{tabular}{|c|c|c|c|c|c|c|}
\hline & & \multicolumn{2}{|c|}{ Female } & \multicolumn{2}{|l|}{ Male } & \multirow{2}{*}{$\begin{array}{l}\text { Difference } \\
\text { in means }\end{array}$} \\
\hline & & Mean & Frequency & Mean & Frequency & \\
\hline \multirow{5}{*}{$\begin{array}{l}\text { Social capital defined } \\
\text { as trust: }\end{array}$} & No social capital & 0.569 & 4229 & 0.577 & 4560 & -0.007 \\
\hline & Bonding social capital & 0.154 & 1147 & 0.144 & 1138 & $0.011 *$ \\
\hline & Bridging social capital & 0.020 & 152 & 0.020 & 157 & 0.001 \\
\hline & $\begin{array}{l}\text { Both bonding and } \\
\text { bridging social capital }\end{array}$ & 0.256 & 1898 & 0.260 & 2053 & -0.004 \\
\hline & Total & & 7426 & & 7908 & \\
\hline $\begin{array}{l}\text { Social capital defined as } \\
\text { support: }\end{array}$ & No social capital & 0.677 & 5454 & 0.716 & 6075 & $-0.038 * * *$ \\
\hline Bonding social capital & 0.205 & 1650 & 0.160 & 1355 & $0.045^{* * *} *$ & \\
\hline Bridging social capital & 0.024 & 197 & 0.027 & 229 & -0.003 & \\
\hline $\begin{array}{l}\text { Both bonding and } \\
\text { bridging social capital }\end{array}$ & 0.093 & 752 & 0.098 & 829 & -0.004 & \\
\hline Total & & 8053 & & 8488 & & \\
\hline
\end{tabular}

Notes: Total sample size is 16,541 . The final column shows the results of two-tailed t-test for the difference in the means. $* * *, * *$, and $*$ indicate the 1,5 , and $10 \%$ levels of significance

Table 3 Neighbours with social capital and dietary diversity by gender of household head

\begin{tabular}{|c|c|c|c|c|c|c|}
\hline & & \multicolumn{2}{|c|}{ Female } & \multicolumn{2}{|l|}{ Male } & \multirow{2}{*}{$\begin{array}{l}\text { Difference } \\
\text { in means }\end{array}$} \\
\hline & & Mean & S.D & Mean & S.D & \\
\hline \multirow[t]{2}{*}{$\begin{array}{l}\text { Social capital } \\
\text { defined as trust: }\end{array}$} & $\begin{array}{l}\text { Number of neighbours with bonding } \\
\text { social capital in } 10 \mathrm{~km} \text { radius }\end{array}$ & 0.408 & 0.203 & 0.416 & 0.203 & $-0.008 * *$ \\
\hline & $\begin{array}{l}\text { Number of neighbours with bridging } \\
\text { social capital in } 10 \mathrm{~km} \text { radius }\end{array}$ & 0.273 & 0.182 & 0.279 & 0.183 & $-0.005^{*}$ \\
\hline \multirow[t]{3}{*}{$\begin{array}{l}\text { Social capital } \\
\text { defined as support: }\end{array}$} & $\begin{array}{l}\text { Number of neighbours with bonding } \\
\text { social capital in } 10 \mathrm{~km} \text { radius }\end{array}$ & 0.175 & 0.127 & 0.183 & 0.133 & $-0.008 * * *$ \\
\hline & $\begin{array}{l}\text { Number of neighbours with bridging } \\
\text { social capital in } 10 \mathrm{~km} \text { radius }\end{array}$ & 0.077 & 0.107 & 0.081 & 0.108 & $-0.005 * * *$ \\
\hline & Household dietary diversity score & 5.502 & 1.595 & 5.535 & 1.580 & -0.034 \\
\hline
\end{tabular}

Notes: Total sample size is 16,541 . The final column shows the results of two-tailed t-test for the difference in the means. $* * *, * *$, and $*$ indicate the 1,5 , and $10 \%$ levels of significance

dietary diversity score, since the difference in dietary diversity score of -0.034 is not statistically valid.

\subsection{Estimation results}

\subsubsection{Relationship of gender and spatial proximity on household social capital status}

Columns (I) and (III) of Table 4 shows that female headed households are more likely to possess bonding social capital than their male counterparts. The results on gender presented in Columns (I) and (III) of Table 4 therefore confirm Hypothesis 


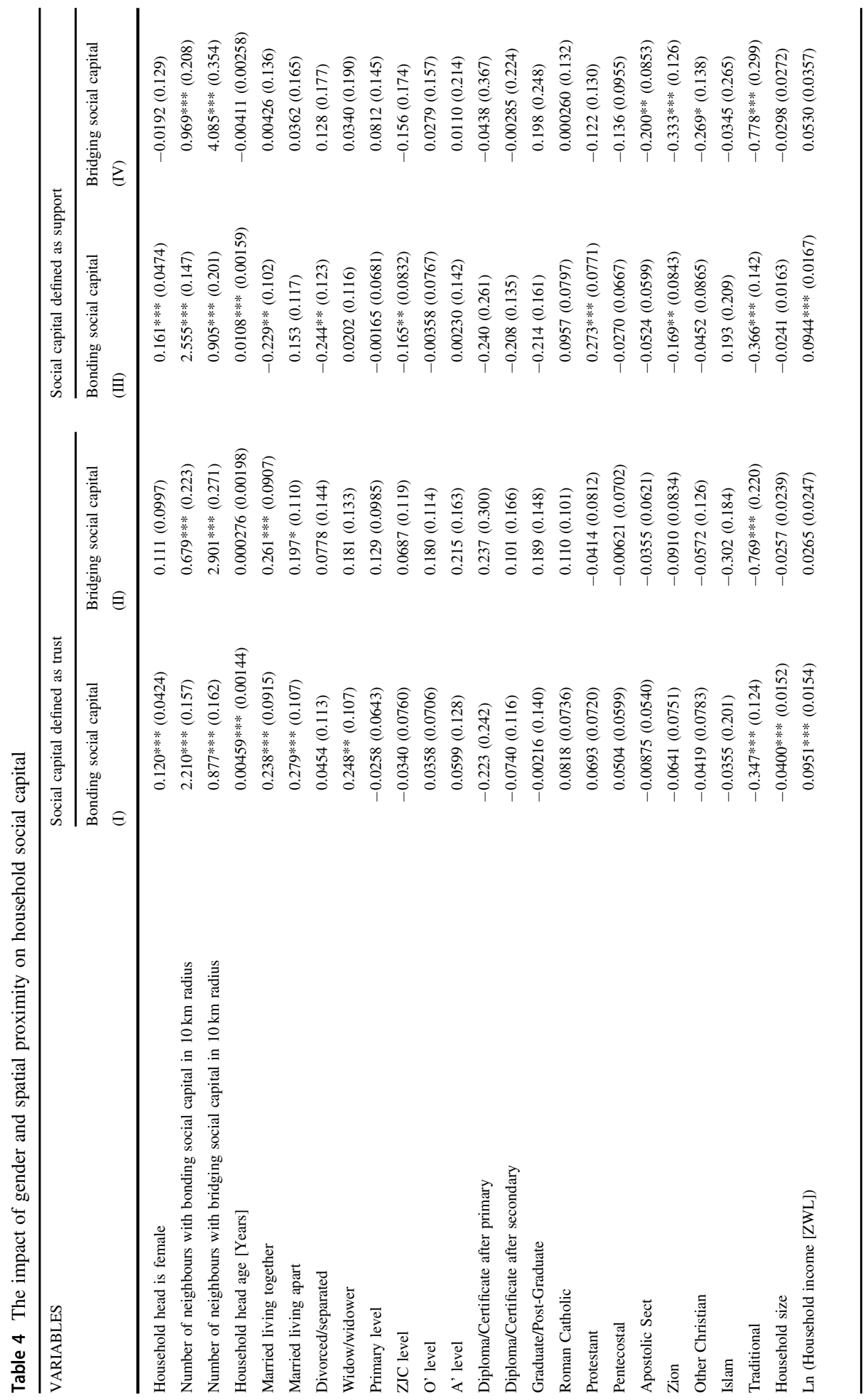




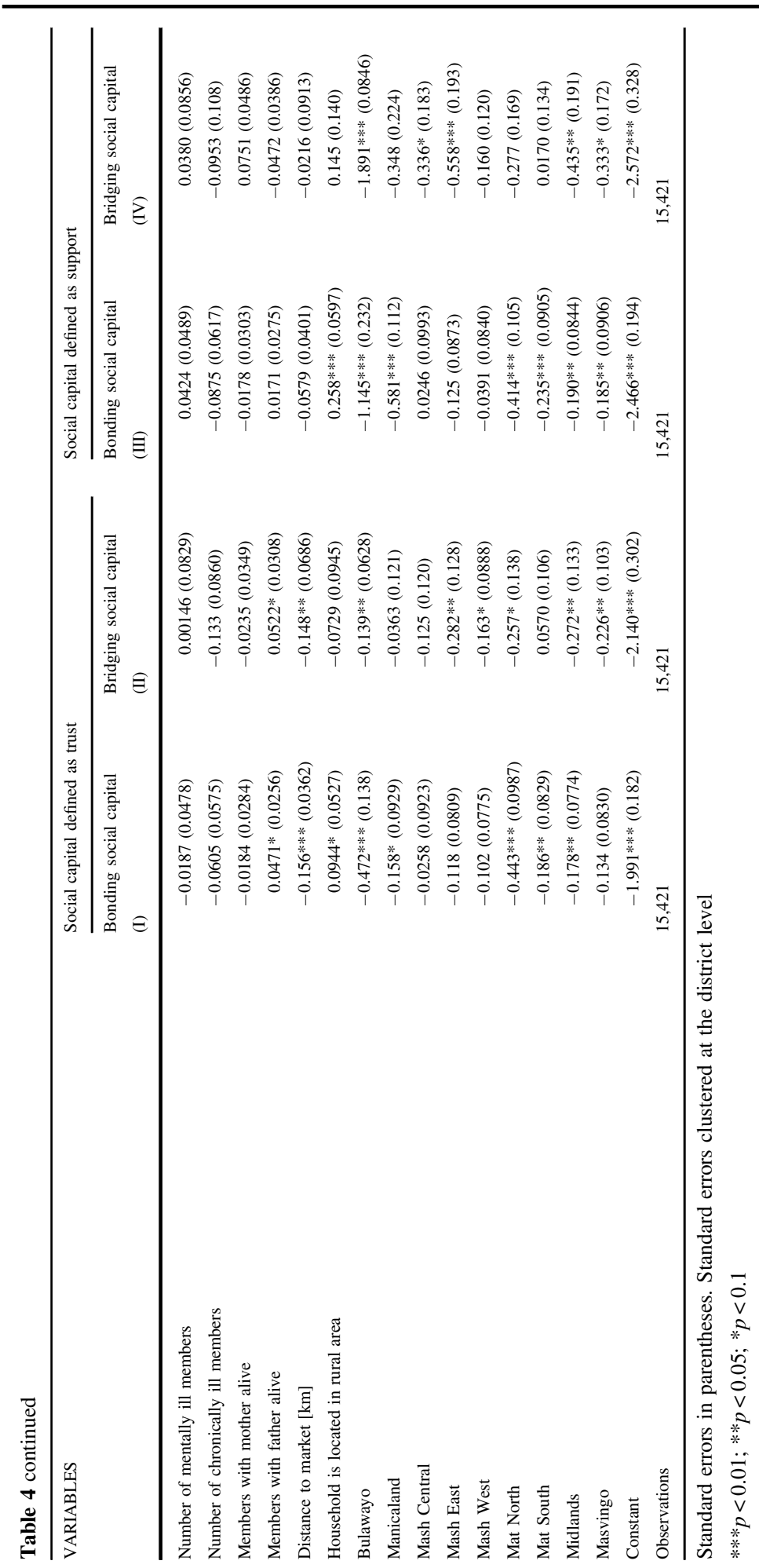


1.1 of this study that female headed households are more likely to possess bonding social capital than their male counterparts after controlling for observed confounding variables. This result is consistent with prior studies for example, Croson et al. (2008) and Charness and Rustichini (2011). The result may emanate from the fact that female household heads are more compelled by their circumstances (which include relatively lower levels of education, relatively more family members who are chronically ill and relatively more rural bias as depicted in the descriptive statistics) to cooperate in bonding social relations for fear of in-group reprisals as propounded by Brody (1993).

Moreover, the results in Columns (II) and (IV) of the table show no statistically significant relationship of the gender of the household head and the propensity to have bridging social capital. The result confirms Hypothesis 1.2 of this study and is consistent with the earlier findings of Croson and Gneezy (2009).

The results in Table 4 also show that the distance weighted number of neighbours within the household's $10 \mathrm{~km}$ radius with either form of social capital increases the potential of the household to have social capital. The result is even more pronounced if neighbours in the household's vicinity have similar form of social capital. This result is robust to variation in the measure of distance to neighbours with social capital in the household's vicinity from $10 \mathrm{~km}$ to $5 \mathrm{~km}$ or $20 \mathrm{~km}$. The result confirms Hypothesis 2 that households are more likely to be spatially located in proximity to other households with similar form of social capital. This result is consistent with results in literature (Moser \& Holland, 1998; Kozel \& Parker, 2000; Woolcock \& Narayan, 2000) that families with similar economic and social relations tend to live clustered together.

\subsubsection{The impact of social capital on household food security}

Table 5 shows treatment effects of social capital on household food security. Consistent with Hypothesis 3 of this study, the results in the table shows that increases in both bonding and bridging social capital improves food security. Column (I) shows that households with bonding social capital increase their food security proxied by

Table 5 PSM estimates of treatment effects of social capital on household dietary diversity score

\begin{tabular}{llll}
\hline & Variables & $\begin{array}{l}\text { PSM estimates of treatment } \\
\text { effects } \\
\text { (I) }\end{array}$ & $\begin{array}{l}\text { IPWRA estimates of treatment } \\
\text { effects } \\
(\mathrm{II})\end{array}$ \\
\hline $\begin{array}{l}\text { Social } \\
\text { capital } \\
\text { defined }\end{array}$ & Bonding social capital & $0.234^{* * *}(0.0295)$ & $0.229 * * *(0.0239)$ \\
$\begin{array}{l}\text { as trust } \\
\begin{array}{l}\text { Social } \\
\text { capital } \\
\text { defined }\end{array}\end{array}$ & Bonding social capital & $0.256^{* * *}(0.0346)$ & $0.126^{* * *}(0.0264)$ \\
$\begin{array}{l}\text { as } \\
\text { support }\end{array}$ & Bridging social capital & $0.157^{* * *}(0.0524)$ & $0.282^{* * *}(0.0263)$ \\
\hline
\end{tabular}

Standard errors in parentheses. Standard errors clustered at the district level

$* * * p<0.01 ; * * p<0.05 ; * p<0.1$ 
the household dietary diversity score by 0.27 points whereas those with bridging social capital increases their food security by 0.149 points. This result is in resonance with specification of social capital as actual reception in the past. Furthermore, the PSM results are robust to change in estimation procedure to IPWRA as shown in Column (II). In summary even though both bonding and bridging social capital improve food security, the impact of bridging social capital is lower than that of bonding social capital which is to a large extent in resonance with Astone et al. (1999), Buchenrieder and Dufhues (2006) and Zhang et al. (2011) who stipulate that bonding social capital rather than bridging social capital is associated with households getting by.

\subsubsection{Gender heterogeneity in the impact of social capital on food security}

Table 6 shows the propensity score matching estimates of gender heterogeneity in the impact of social capital on household dietary diversity score. The result shows that the impact of social capital on household dietary diversity score is higher when the household head is female rather than male. This applies for both bonding and bridging social capital and whether social capital is measured as trust or actual support received. This finding confirms Hypothesis 4 of this study and is consistent with studies which argue that, women cooperate more in their bonding relations which increases their likelihood to get assistance during times of food insecurity (Charness \& Rustichini, 2011; Croson et al., 2008). The study argues that coping strategies should target putting the family at the core of inclusive development agendas such as food and nutrition assistance programmes that are organised based on family structures in order to maximise the likelihood of easing food insecurity within communities.

\subsection{Robustness checks to observed heterogeneity}

Table 7 presents results from covariate balance tests to appraise the comparability of covariates before and after matching. $P$ values for the equality of means of covariates like household size, household income, some education dummies, as well as several province dummies are smaller than 0.05 before matching but larger than 0.1 after matching. This indicates that covariates were unbalanced before matching but became balanced after matching. Failure to reject the hypothesis of joint equality of means after matching indicated by a $p$ value larger than 0.05 , shows that covariates for households that have social capital and those that did not have social capital are drawn from comparable distributions (Caliendo \& Kopeinig, 2008). Additionally, a mean absolute bias of $2.1 \%$ is far smaller than the $5 \%$ recommended to yield reliable estimates (Rosenbaum \& Rubin, 1985).

In addition, we varied the distance to 5 and $20 \mathrm{~km}$ and observed minimal decrease and increase in the composition of neighbours' social capital respectively. Thus our results are not overly sensitive to changes in distance in defining the household neighbours. 


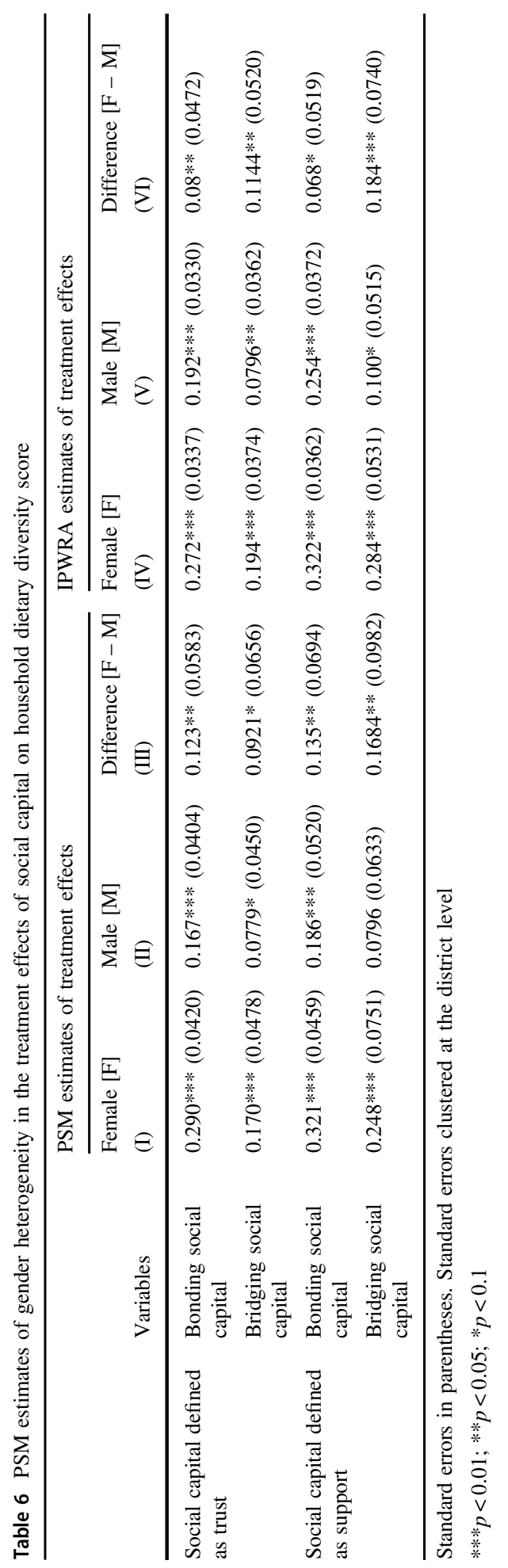




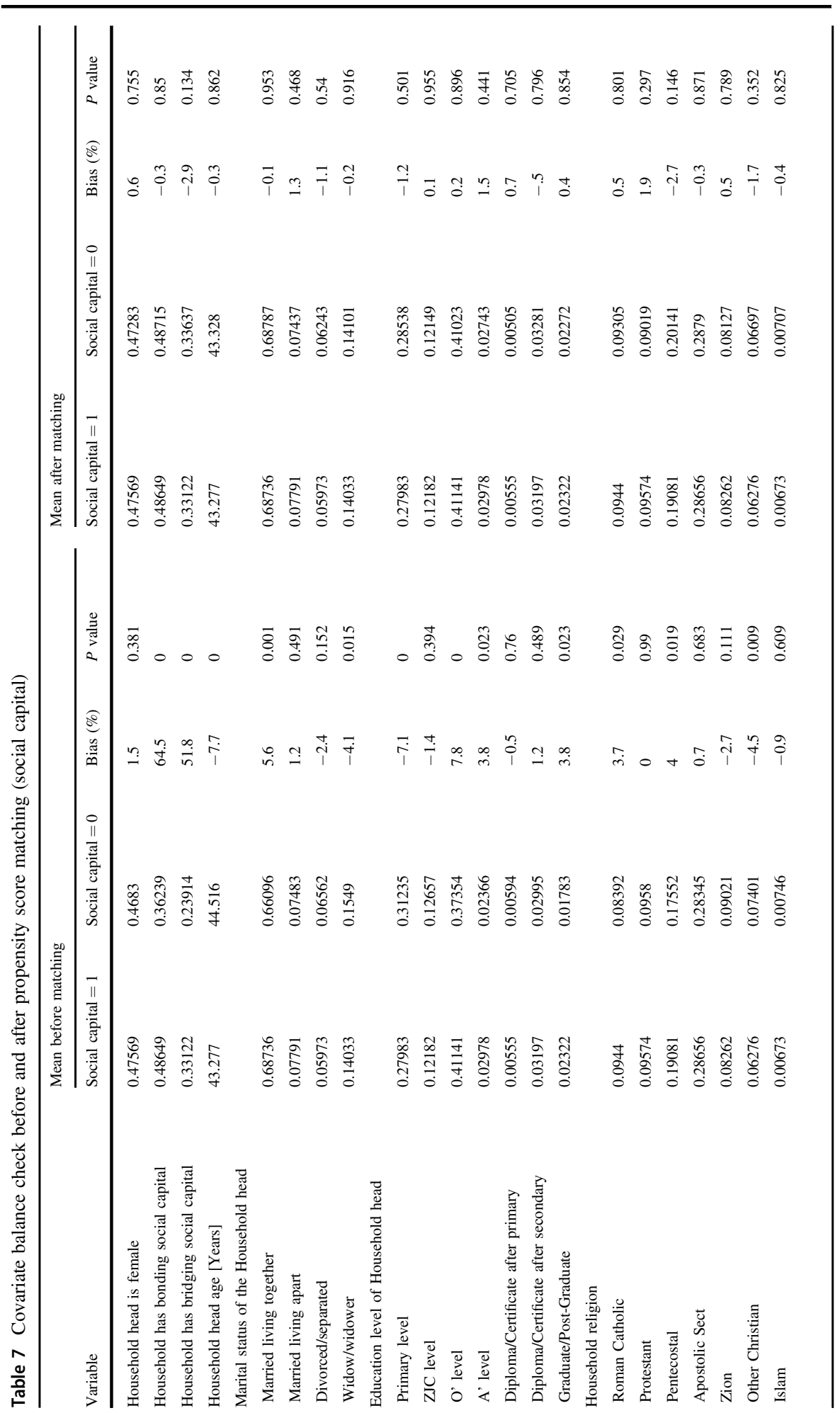




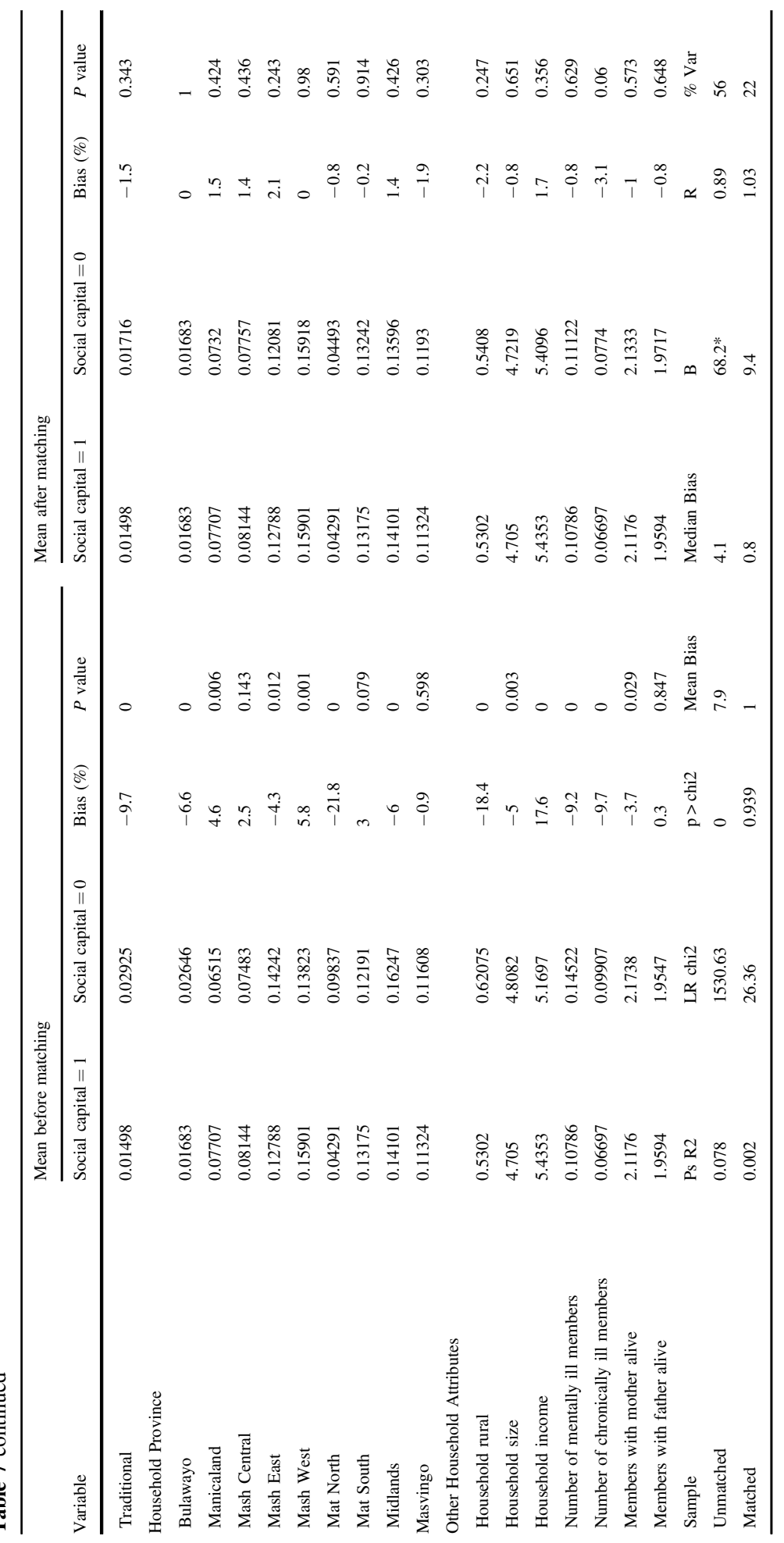




\section{Conclusion}

On the basis of a large-scale data that was carried out in 2019 by the Zimbabwe Vulnerability Assessment Committee (ZIMVAC), the study analysed the gender heterogeneity in the impact of bonding and bridging social capital on household food security. Specifically, interest was on understanding to what extent gender and spatial interdependence affect the propensity of a household to possess bonding and bridging social capital. Furthermore, the study analysed the extent to which spatial interdependence affects a household's possession of bonding and bridging social capital; and whether social capital influence household food security.

The research findings indicate that female headed households are more likely to have bonding social capital than their male counterparts and that the possession of bridging social capital is statistically balanced between male and female headed households. To some extent, and on the part of bonding social capital, this result is consistent with the findings of Charness and Rustichini (2011). The conclusion that female-headed households exhibit bonding social capital than their male counterparts implies that female-headed households may be more vulnerable to food supply shocks since it is an established fact in literature that bonding social capital is associated with households getting-by. This may call for the empowerment of females so as to improve social development.

Furthermore, the study discovered that spatial proximity to households with social capital improves the probability of a household to possess social capital. This result is consistent with findings in the literature (e.g. Woolcock \& Narayan, 2000). This is interestingly similar to a conclusion reached by Lee et al. (2018) in which they observed extended geographic networks but found that within-community support was more strongly associated with food security than the presence of remote contacts. This result, however, is different from theirs in that ours goes further to unmask the effect of the homogeneity of a household's social capital to that of its neighbour. Homogeneity in characteristics tends to influence clustering. Families with similar economic and social relations tend to live clustered together.

The study also finds that both bonding and bridging social capital improve household food security. Improvements in food security, however, are largely associated with possession of bonding social capital. Households with bonding social capital increase their food security proxied by the household dietary diversity score by 0.27 points whereas those with bridging social capital increases their food security by 0.149 points. This is consistent with an observation in the literature that bonding rather than bridging social capital is associated with households getting-by. Finally, female-headed households are more able to increase food security than their male counterparts when they have both bonding and bridging social capital. This is in line with findings which argue that women cooperate more with their bonding relations thereby increasing their likelihood to get assistance during times of stress.

From a policy point of view, and given the conclusion that food assistance from relatives as opposed to non-relatives is more effective in alleviating food insecurity, it is paramount to invest in approaches that put the family at the core of inclusive development agendas such as public works programs and food and nutrition assistance programmes that are organised based on family structures. There is need, therefore, for the provision of sustained support and encouragement 
of cohesion of the family to enable it to play its role in ensuring food security through social bonding. This requires development and implementation of targeted social policies that address different concerns of families; policies that create appropriate structures, mechanisms and capacities for reacting to the challenges facing the family. Family structure and cohesion in Zimbabwe are threatened by a number of factors such as outmigration, climate change-induced disasters and the gradual erosion of extended family system. This calls for ensuring that interventions to support families acknowledge generational interdependence and supporting intergenerational interaction.

In relation to the finding that female-headed households are more likely to have bonding social capital than their male counterparts, points to the need for policy interventions that focus on close ties, family, and increasing women's resources and capacity to enhance nutritional benefits hence improving sustainability of food security interventions. Interventions from development partners such as NGOs in Zimbabwe may employ strategies that will allow women to use their bonding capital as collateral.

We would however want to point out that, social networks do not seem to provide a feasible solution to the food insecurity problem in times of systemic shocks which affect all households. Such situations are beyond the scope of this study.

\section{Compliance with ethical standards}

Conflict of interest The authors declare no competing interests.

Publisher's note Springer Nature remains neutral with regard to jurisdictional claims in published maps and institutional affiliations.

Open Access This article is licensed under a Creative Commons Attribution 4.0 International License, which permits use, sharing, adaptation, distribution and reproduction in any medium or format, as long as you give appropriate credit to the original author(s) and the source, provide a link to the Creative Commons license, and indicate if changes were made. The images or other third party material in this article are included in the article's Creative Commons license, unless indicated otherwise in a credit line to the material. If material is not included in the article's Creative Commons license and your intended use is not permitted by statutory regulation or exceeds the permitted use, you will need to obtain permission directly from the copyright holder. To view a copy of this license, visit http://creativecommons.org/licenses/by/4.0/.

\section{References}

Abreu, D. (1988). On the theory of infinitely repeated games with discounting. Econometrica, 56(2), 383-396. https://doi.org/10.2307/1911077.

Acemoglu, D., Johnson, S., \& Robinson, J. (2001). The colonial origins of comparative development: an empirical investigation. American Economic Review, 91(Dec), 1369-1401. https://doi.org/10.1257/a er.91.5.1369.

Acemoglu, D., Johnson, S., \& Robinson, J. (2002). Reversal of fortune: geography and institutions in the making of the modern world income distribution. Quarterly Journal of Economics, 118, 1231-94. https://doi.org/10.1162/003355302320935025.

Acemoglu, D., Johnson, S., \& Robinson, J. (2005). The rise of Europe: Atlantic trade, institutional change, and economic growth. American Economic Review, 95(3), 546-79. https://doi.org/10.1257/ 0002828054201305 . 
Akerlof, G. A. (1970). The market for lemons: quality uncertainty and the market mechanism. Quarterly Journal of Economics, 84(3), 488-500. https://doi.org/10.2307/1879431.

Astone, N., Nathanson, C., Schoen, R., \& Kim, Y. (1999). Family demography, social theory, and investment in social capital. Population and Development Review, 25(1), 1-31. https://doi.org/10. 1111/j.1728-4457.1999.00001.x.

Austin, P. C. (2009). Type I error rates, coverage of confidence intervals, and variance estimation in propensity- score matched analyses. International Journal of Biostatistics, 5(1), 1557-4679. https:// doi.org/10.2202/1557-4679.1146.

Austin, P. C. (2011). An introduction to propensity score methods for reducing the effects of confounding in observational studies. Multivariate Behavioral Research, 46(3), 399-424. https://doi.org/10.1080/ 00273171.2011 .568786 .

Banerjee, A. V., \& Duflo, E. (2011). Poor economics: a radical rethinking of the way to fight global poverty. New York, NY: Perseus Books.

Bardhan, P. (1997). Corruption and Development: A Review of Issues. Journal of Economic Literature, 35(3),1320-1346. http://www.jstor.org/stable/2729979.

Bourdieu, P., Coleman, J., \& Coleman, Z. (1992). Social theory for a changing society. New York, NY: Routledge. 10.4324/9780429306440.

Brody, L. R. (1993). On understanding gender differences in the expression of emotion: Gender roles, socialization, and language. In SL Ablon, D Brown, EJ Khantzian, \& JE Mack (Eds.), Human feelings: explorations in affect development and meaning (p. 87-121). Analytic Press, Inc.

Buchenrieder, G., \& Dufhues, T. (ed.) 2006. "Making rural households' livelihoods more resilient: The importance of social capital and the underlying social networks," Studies on the Agricultural and Food Sector in Transition Economies, Leibniz Institute of Agricultural Development in Transition Economies (IAMO), volume 34, number 93010.

Caliendo, M., \& Kopeinig, S. (2008). Some practical guidance for the implementation of propensity score matching,. Journal of Economic Surveys, 22(1), 31-72. https://doi.org/10.1111/j.1467-6419. 2007.00527.x.

Carletto, C., Zezza, A., \& Banerjee, R. (2013). Towards better measurement of household food security: Harmonizing indicators and the role of household surveys. Global Food Security, 2(1), 30-40. https:// doi.org/10.1016/j.gfs.2012.11.006.

Charness, G., \& Rustichini, A. (2011). Gender differences in cooperation with group membership. Games and Economic Behavior, 72, 77-85. https://doi.org/10.1016/j.geb.2010.07.006.

Chriest, A., \& Niles, M. (2018). The role of community social capital for food security following an extreme weather event. Journal of Rural Studies, 64, 80-90. https://doi.org/10.1016/j.jrurstud.2018.09.019.

Croson, R., \& Gneezy, U. (2009). Gender differences in preferences. Journal of Economic Literature, 47 (2), 448-474. https://doi.org/10.1257/jel.47.2.448.

Croson, R., Marks, M., \& Snyder, J. (2008). Groups work for women: gender and group identity in social dilemmas. Negotiation Journal, 24, 411-427. https://doi.org/10.1111/j.1571-9979.2008.00195.x.

Durlauf, S. N., \& Fafchamps, M. (2005). Social capital, In Aghion, P. \& Durlauf, S.N. (Ed.) Handbook of economic growth, vol. 1B, (pp. 1639-1699). North Holland, Amsterdam: Elsevier. https://doi.org/10. 3386/w10485.

Eagly, A. H. (1987). Sex differences in social behavior: a social-role interpretation. Hillsdale, NJ: Lawrence Erlbaum. 10.4324/9780203781906.

Eckel, C. C., \& Grossman, P. J. (2008). Men, women and risk aversion: experimental evidence. vol. 1 of handbook of experimental economics results. Elsevier, Ch. 113, 1061-1073. https://doi.org/10.1016/ S1574-0722(07)00113-8.

Ehsan, A., Klaas, H. S., Bastianen, A., \& Spini, D. (2019) Social capital and health: a systematic review of systematic reviews. SSM-Population Health, 8, https://doi.org/10.1016/j.ssmph.2019.100425.

Fafchamps, M., \& Minten, B. (1999). Relationships and traders in Madagascar. Journal of Development Studies, 35(6), 1-35. https://doi.org/10.1080/00220389908422600.

FAO, IFAD, UNICEF, WFP \& WHO (2019). The State of Food Security and Nutrition in the World. Safeguarding against economic slowdowns and downturns. Rome: FAO..

FAO. (2015). Regional overview of food insecurity: African food security prospects brighter than ever. Accra: FAO.

Gilligan, C. (1982). In a different voice: psychological theory and women's development. Cambridge, Massachusetts: Harvard University Press.

Giordano, R., Lanau, S., Tommasino, P., \& Topalova, P. (2015). Does public sector inefficiency constrain firm productivity: evidence from Italian Provinces, International Monetary Fund Working Paper WP/15/168. 
Granovetter, M. S. (1985). Economic action and social structure: the problem of embeddedness,. American Journal of Sociology, 91(3), 481-510. https://doi.org/10.1086/228311.

Gibson, M. (2012). The feeding of nations: redefining food security for the 21 st century. Boca Raton: CRC Press. 10.1201/b11576.

Gundersen, C., \& Kreider, B. (2009). Bounding the effects of food insecurity on children's health outcomes. Journal of Health Economics, 28, 971-83. https://doi.org/10.1016/j.jhealeco.

Heckman, J. J., Ichimura, H., \& Todd, P. E. (1997). Matching as an econometric evaluation estimator: evidence from evaluating a job training programme,. Review of Economic Studies, 64(4), 605-654. https://doi.org/10.2307/2971733.

Howard, L. L. (2011). Does food insecurity at home affect non-cognitive performance at school? A longitudinal analysis of elementary student classroom behavior. Economics of Education Review, 30, 157-76. https://doi.org/10.1016/j.econedurev.2010.08.003.

Huang, J., Oshima, K., \& Kim, Y. (2010). Does food insecurity affect parental characteristics and child behavior?Testing mediation effects. Social Service Review, 84, 381-401. https://doi.org/10.1086/ 655821.

Jennings, C., \& Sanchez-Pages, S. (2017). Social capital, conflict and welfare. Journal of Development Economics, 124, 157-167. https://doi.org/10.1016/j.jdeveco.2016.09.005.

Kozel, V., \& Parker, B. (2000). Integrated approaches to poverty assessment in India. In Michael Bamberger ed., Integrating quantitative and qualitative research in development projects (pp. 58-69). Washington, D.C: World Bank.

Kuwabara, K. (2005). Nothing to fear but fear itself: Fear of fear, fear of greed and gender effects in twoperson asymmetric social dilemmas. Social Forces, 84, 1257-1272. https://doi.org/10.1353/sof. 2006.0020.

Lee, G. O., Surkan, P. J., Zelner, J., Olortegui, M. P., Yori, P. P., Ambikapathi, R., Caulfield, L. E., Gilman, R. H., \& Kosek, M. N. (2018). Social connectedness is associated with food security among peri-urban Peruvian Amazonian communities. SSM Population Health, 4, 254-262. https://doi.org/ 10.1016/j.ssmph.2018.02.004.

Lenhart, O. (2021). The effects of paid family leave on food insecurity-evidence from California. Review of Economics of the Household. https://doi.org/10.1007/s11150-020-09537-4.

Lippman, S. A., Maman, S., MacPhail, C., Twine, R., Peacock, D., Kahn, K., \& Pettifor, A. (2013). Conceptualizing community mobilization for HIV prevention: implications for HIV prevention programming in the African context. PloSone, 8(10), e78208 https://doi.org/10.1371/journal.pone. 0078208.

Misselhorn, C. (2009). Empathy with inanimate objects and the uncanny valley, Minds and Machines vol. 19, 345-359. https://doi.org/10.1007/s11023-009-9158-2.

Moser, C., \& Holland, J. (1998). Can policy-focused research be participatory? Research on violence and poverty in Jamaica using PRA methods. In Holland, J \& Blackburn, J. (Eds.), Whose voice? Participatory research and policy change. London: Intermediate Technology Publications.

Putnam, R. D. (2000). Bowling alone: the collapse and revival of American community. New York, NY: Simon \& Schuster. https://doi.org/10.1145/358916.361990.

Rosenbaum, P., \& Rubin, D. (1985). Constructing a control group using multivariate matched sampling methods that incorporate the propensity score. The American Statistician, 39(1), 33-38. https://doi. org/10.1080/00031305.1985.10479383.

Ruel, M. T. (2002). Is dietary diversity an indicator of food security or dietary quality? A review of measurement issues and research needs. FCND Discussion Paper No. 140. Washington, DC: IFPRI.

Shaw, D. J. (2007). World food security. A history since 1945. New York, NY: Palmgrave Macmillan. $10.1057 / 9780230589780$.

Stavropoulou, M., Holmes, R., \& Jones, N. (2016). Harnessing informal institutions to strengthen social protection for the rural poor. Global Food Security, 12, 73-79. https://doi.org/10.1016/j.gfs.2016. 08.005 .

Thorat, S. (2009). Economic exclusion and poverty linkages: a reflection on concept, consequences, and remedies in an Asian context. In: The poorest and hungry: assessments, analyses and actions. Washington, D. C., IFPRI.

United Nations (2017). Department of Economic and Social Affairs, Population Division (2017). Household Size and Composition Around the World 2017 - Data Booklet (ST/ESA/SER.A/405).

vanStaveren, I., \& Knorringa, P. (2007). Unpacking social capital in economic development: how social relations matter. Review of Social Economy, 65(1), 107-35. https://doi.org/10.1080/ 00346760601132147. 
Williamson, C. R., \& Easterly, W. (2015). The Tyranny of experts: economists, dictators, and the forgotten rights of the poor. Public Choice, 163, 405-408. https://doi.org/10.1007/s11127-015-0257-8.

Woolcock, M., \& Narayan, N. (2000). Social capital: implications for development theory, research, and policy. The World Bank Research Observer, 15(2), 225-49. https://doi.org/10.1093/wbro/15.2.225.

Zhang, S., Anderson, S. G., \& Zhan, M. (2011). The differentiated impact of bridging and bonding social capital on economic well-being: an individual level perspective. The Journal of Sociology \& Social Welfare, 38(1), 7. 